\title{
Effects of Cadmium Exposure on Lipid Peroxidation and Chlorinative Stress of Rat Kidney
}

\author{
Eko Suhartono ${ }^{1,2^{*}}$, Triawanti $^{2}$, Amin Setyo Leksono $^{3}$, Muhammad Sasmito Djati $^{3}$ \\ ${ }^{1}$ Doctoral Program of Environmental Studies, University of Brawijaya, Malang, Indonesia \\ ${ }^{2}$ Biochemistry Division, Faculty of Medical, Lambung Mangkurat University, Banjarmasin, Indonesia \\ ${ }^{3}$ Department of Biology, Faculty of Mathematics and Natural Sciences, University of Brawijaya, Malang, \\ Indonesia
}

\begin{abstract}
In addition to a wide range of adverse effects on human health, toxic metals such as cadmium (Cd) can promote kidney damage. In this study, we proposed the toxicological properties of these metals which are partly related to lipid peroxidation and chlorinative stress. Thus our study aimed to measure the lipid peroxidation and chlorinative stress in kidney of rats exposed to $\mathrm{Cd}$. The study was performed on 32 male rats (Rattus novergicus) weighing $300 \pm 10$ grams with normal activity. Rats were acclimatized for a week before the treatment. The animals were divided into two major groups with one group for control $\left(\mathrm{K}_{0}\right)$ and the other groups were exposed to $3 \mathrm{mg} / \mathrm{L} \mathrm{CdSO}{ }_{4}$ through the drinking water. The animals in each groups were divided again into two small groups with different time of exposure. The time of exposure are subacute (six weeks) and subchronic (eight weeks). After the exposure the kidney from all treated animals showed the significant increase of MDA and AOPP levels. In conclusion, subacute and subchronic exposure of Cd caused the kidney damage through lipid peroxidation and chlorinative stress, as shown by increasing of MDA and AOPP levels.
\end{abstract}

Keywords: AOPP, Cadmium, Chlorinative Stress, Lipid Peroxidation, MDA

\section{INTRODUCTION}

Cadmium (Cd) is a heavy metal often used by humans for wide range of industrial materials, for example $\mathrm{CdS}$ and $\mathrm{CdSeS}$ compound widely used as dye, $\mathrm{CdSO}_{4}$ used in the battery industry for Weston cell compartment, $\mathrm{CdBr}_{2}$ abd $\mathrm{CdCl}_{2}$ used in photography, $\left(\mathrm{C}_{2} \mathrm{H}_{5}\right)_{2} \mathrm{Cd}$ used in the tetraethyl$\mathrm{Pb}$ producing, etc. In other side, industrial waste containing cadmium can enter into the water and at certain concentration it will become the source of toxin to aquatic life organism. Cadmium pollution can disrupt the stability and diversity of aquatic ecosystems. From the ecological aspect, degradation of aquatic ecosystems due to pollution of $\mathrm{Cd}$ can be determined through level and continuity of incoming contaminants into the water, toxicity characteristic, and bioaccumulation [1].

In South Kalimantan, $\mathrm{Cd}$ levels from construction and mining industry activity has polluted the aquatic environment. It was reported that $\mathrm{Cd}$ level in sediments sampled from Trisakti, Basirih, and Banjar Raya at South

\footnotetext{
"Correspondence author:

Eko Suhartono

Email : ekoantioxidant@gmail.com

Address : Doctoral Program of Environmental Studies, University of Brawijaya, Jl. Mayjen Haryono No. 169, Malang, 65145
}

Kalimantan already exceeded the threshold value $\left(<1 \mathrm{mg} . \mathrm{L}^{-1}\right)$ up to $1.019 \mathrm{mg} . \mathrm{L}^{-1}, 1.138 \mathrm{mg} . \mathrm{L}^{-1}$, respectively [2]. Other study showed that the abandoned acid mine drainage of coal mine contained Cd level reach 23.7 mg. L $^{-1}$ [3]. In addition, it was also reported that levels of $\mathrm{Hg}$, $\mathrm{Pb}$, and $\mathrm{Cd}$ contained in water bodies of Barito river basin exceeded the threshold value. This is presumably caused by the transport and unloading of coal activities passed through the river stream [3-4]. Increase levels of $\mathrm{Cd}$ in the waters cause some marine biota also has been polluted by $\mathrm{Cd}$. A study mentioned that some species of shrimps and crabs in Takisung and Batakan South Kalimantan has been contaminated by $\mathrm{Cd}$ (mean of $0.213 \mathrm{mg} \cdot \mathrm{kg}^{-1}$ ) [5].

The pollution cause $\mathrm{Cd}$ enters into the body. Cadmium will lead to damage to various organs, especially liver and kidney which begun of cellular damage level. $\mathrm{Cd}$ is metabolized through biotransformation mechanism involving cytochrome P-450 in the mitochondria. Additionally, Cd that entered the body can lead to cytokines activation by releasing various inflammatory mediators. Induction of $\mathrm{Cd}$ caused increasing Tumor Necrosis Factor Alpha (TNF- $\alpha$ ) as mediator of inflammation in rat [6]. This is caused by the activation of macrophages that produce cytokines. Furthermore, cytokine produce various inflammatory mediators, 
including TNF- $\alpha$ and NFK $\beta$ [7]. On the other hand, macrophages also phagocyte cadmium by releasing $\mathrm{H}_{2} \mathrm{O}_{2}$ and $\bullet \mathrm{O}_{2}$.

Resulted $\mathrm{H}_{2} \mathrm{O}_{2}$ molecules will be catalyzed by myeloperoxidase to form hypochlorite anion $(\mathrm{HOCl})$. Then, $\mathrm{HOCl}$ will react with the amino groups of proteins to form chloramine. If antioxidant capacity is not able to reduce the reactivity of $\mathrm{HOCl}$ so chlorinative stress will be occured. Advanced Oxidation Protein Products (AOPP) is a good marker for chlorinative stress of derivative phagocytes determination. The increase of AOPP reflects increasing $\mathrm{H}_{2} \mathrm{O}_{2}$ formation, myeloperoxidase activity enhancement, and increasing reactivity of hypochlorite anion to biomolecules containing the amino groups such as proteins in the cell structure [8].

Beside to induce inflammation, Cadmium also able to bind covalently with various ligands, such as - $\mathrm{OH},-\mathrm{COO}-,-\mathrm{OPO}_{3} \mathrm{H}-,-\mathrm{C}=\mathrm{O},-\mathrm{SH},-\mathrm{SS}-,-\mathrm{NH}_{2}$ and $-\mathrm{NH}$, which abundant contained in amino acids as protein or enzyme constituent. Bond between $\mathrm{Cd}$ and ligands will inhibit the activity of antioxydative enzymes resulting in oxydative balance disorders $[9,10]$. This imbalance will lead to increase free radicals and oxidants so it also damage biomolecules of membrane constituent through formation of lipid peroxidation.

Since lipid peroxidation and chlorinative stress might be involved in kidney damage during $\mathrm{Cd}$ exposure. Thus our study was aimed to investigate effect of $\mathrm{Cd}$ exposure in kidney of rats through lipid peroxidation via MDA and chlorinative stress via AOPP formations.

\section{MATERIALS AND METHODS}

This study design was a true experimental study design, and examine the impact of $\mathrm{Cd}$ exposure in kidney of rats for different time of exposure. The rats were divided into two major experimental groups, for each groups consists of 16 rats and housed in standard rat cages. One set of rats in a group served as the control $\left(\mathrm{K}_{0}\right)$ while the other served as the test $\left(K_{1}\right)$. The control groups were provided with distilled water as drinking-water while the test groups were provided with aqueous solution of $\mathrm{CdSO}_{4}$ containing the equivalent of $3 \mathrm{mg} \cdot \mathrm{L}^{-1}\left(\mathrm{~K}_{1}\right)$ for six and eight weeks. Animals had free access to standard laboratory rat pellet and water ad libitum. At the end of treatment period the kidney was removed surgically under the anasthesia. Then the kidney was cut into small pieces and ground to form a liquid. Subsequently,
$5 \mathrm{ml}$ of the solution was taken and centrifuged at $3500 \mathrm{rpm}$ for 10 minutes. The top layer of $200 \mathrm{~mL}$ were taken to be examined.

\section{Preparing kidney homogenate}

After dissection, the kidney removed and immediately fixed in phosphate buffer solution $\mathrm{pH}$ 7. Then the kidney was cut into small pieces and crushed to formed liquid. Subsequently, $5 \mathrm{~mL}$ of the solution was taken and centrifugated at $3500 \mathrm{rpm}$ for 10 minutes. Supernatant was taken as much $200 \mu \mathrm{L}$ to be checked levels of malondialdehyde (MDA) and Advanced Oxidation Protein Products (AOPP).

\section{MDA level determination}

A total of $1 \mathrm{~mL}$ of kidney homogenate was added with $1 \mathrm{~mL}$ of distilled water, then put in the Eppendorf tube. After that, $100 \mu \mathrm{L}$ TCA 100\%, $100 \mu \mathrm{L} \mathrm{Na-Tiobarbiturat} \mathrm{1 \% ,} \mathrm{and} 250 \mu \mathrm{L} \mathrm{HCl} 1 \mathrm{M}$ were successively added. The solution was heated at $100^{\circ} \mathrm{C}$ for 20 minutes then centrifugated at $3500 \mathrm{rpm}$ for 10 minutes. Thereafter, the supernatant was taken and added with distilled water until $3500 \mu \mathrm{L}$. Level of MDA (absorbance) was measured using spectrophotometer with maximum wavelength of $540 \mathrm{~nm}$ [11].

\section{AOPP level determination}

Sample solution was prepared by mixing 200 $\mu \mathrm{L}$ of homogenate, $600 \mu \mathrm{L}$ of $20 \mathrm{mM}$ phosphate buffer $\mathrm{pH} 7,4$ and $100 \mu \mathrm{L}$ of $\mathrm{KI} 1.16 \mathrm{M}$. While, blanko solution was prepared by mixing $800 \mu \mathrm{L}$ of phosphate buffer with $100 \mu \mathrm{L}$ of $\mathrm{KI} 1.16 \mathrm{M}$. Sample and blanko solutions were left for two minutes then added with $200 \mu \mathrm{L}$ of $10 \%$ acetic acid, and measured the absorbance at maximum wavelength of $340 \mathrm{~nm}$. AOPP concentration was calculated by $A=\varepsilon$ b $C$ where $\varepsilon=26 \mathrm{mM}^{-1} \mathrm{~cm}^{-1}$ dan $b=1 \mathrm{~cm} \mathrm{[12].}$

\section{Data analysis}

The obtained data was shown as mean and the standard deviation $( \pm S D)$. The data was prior to analyzed using Kolmogorov-Smirnov normality test and Levene homogenity. If the data was normally distributed and homogeneous then tested by one-way analysis of variance test (One Way ANOVA) and continued using Tuckey HSD test. Data analysis was performed using SPSS version 17.0 with $95 \%$ confidence level $(\alpha=0.05)$. 


\section{RESULT AND DISCUSSION}

The concentrations of MDA and AOPP in the kidney homogenate exposed to $\mathrm{Cd}$ in different time of exposure are shown in Table 1, with corresponding levels in controls. After the administration of $3 \mathrm{mg} . \mathrm{L}^{-1}$ cadmium, MDA levels in the kidney homogenate increased significantly in both time of exposure compared to controls $(p<0,05)$. There was a time dependent increase in MDA levels in the kidney homogenate and they were higher in the subchronic exposure.

Table 1. Mean of MDA $(\mu \mathrm{M})$ and AOPP $(\mu \mathrm{M})$ levels in rat kidney before and after $\mathrm{Cd}$ treatment

\begin{tabular}{lccc}
\hline Group & \multicolumn{3}{c}{ Exposure time } \\
\cline { 2 - 4 }$(\mu \mathrm{M})$ & Control & Subacute & Subchronic \\
\hline MDA & $46.14 \pm 2.49$ & $105.57 \pm 4.62^{*}$ & $136.02 \pm 4.58^{*}$ \\
AOPP & $0.97 \pm 0.36$ & $10.28 \pm 0.25^{*}$ & $11.68 \pm 0.43^{*}$ \\
\hline
\end{tabular}

Malondialdehyde (MDA) was a parameter of lipid oxidative damage caused by free radicals and oxidants. The formation of MDA was started from polyunsaturated fatty acids containing two or more double bonds which highly susceptible to oxidation by hydroxyl radicals and peroxide compounds. Hydroxyl radical or peroxide compounds would attract hydrogen atoms of the double bond of unsaturated fatty acids and formed lipid peroxyl radicals. This radical compounds then reacted with other unsaturated fatty acids to formed lipid hydroperoxide and new lipid peroxyl radicals. This oxidation reaction continued to other lipid, or well-known as lipid autoxidation or lipid peroxidation process. The process would also form cyclic endoperoxide which broke down into malondialdehyde. MDA was one of molecules formed during lipid peroxidation as product of endoperoxide breaking down. MDA became into measuring tool widely used as an indicator of lipid peroxidation [13].

In this study, MDA levels increased along with the increasing concentration and duration of $\mathrm{Cd}$ exposure. This was caused by several mechanisms:

a. Cd involved in Fenton or Haber-Weiss reaction that transformed peroxide compounds into reactive hydroxyl radicals. The hydroxyl radicals subsequently oxidized unsaturated fatty acids and formed stable MDA [13].

b. The mechanism of respiratory burst due to cadmium caused increasing formation of peroxide compounds. Increase of peroxide would oxidize unsaturated fatty acids and formed MDA.
Thus, along with increase of concentration and duration of $\mathrm{Cd}$ exposure, the MDA levels would also increase. This was consistent with studied by Kara, the rats were injected subcutaneously with $\mathrm{CdCl}_{2}$ each dose of 0.5 mg. $\mathrm{kg}^{-1}, 1 \mathrm{mg} \cdot \mathrm{kg}^{-1}, 2 \mathrm{mg} \cdot \mathrm{kg}^{-1}, 4 \mathrm{mg} \cdot \mathrm{kg}^{-1}$. After 24 hours, rats were dissected and measured levels of MDA serum. The results of that study could be concluded that the increase of $\mathrm{CdCl}_{2}$ injected dose caused enhancement of MDA serum levels formation [14].

Another study also reported that the treatments of $\mathrm{CdCl}_{2}$ with $1 \mu \mathrm{M}, 50 \mu \mathrm{M}$, and 150 $\mu \mathrm{M}$ concentration to human erythrocytes significantly increased the levels of MDA [15]. Along with enhancement of $\mathrm{Cd}$ concentration, production of MDA was also higher.

This results were supported by Aflanie et al. [16] who treated liver homogenate using $\mathrm{Cd}^{2+}$ with concentration of 0.003 and $0.006 \mathrm{mg} \cdot \mathrm{L}^{-1}$. The observation was carried out on days 2,4 , and 6 . The results showed that there was positive correlation between reaction time with the formation of MDA $\left(R^{2}=0.81 ; p<0.05\right)$, which indicated the longer exposure time of $\mathrm{Cd}^{2+}$, MDA formed would also increase. In addition, the enhancement of $\mathrm{Cd}^{2+}$ concentration also increased the levels of MDA.

The result from table 1 also showed that $\mathrm{Cd}$ exposure could increased the AOPP level significantly, compared to controls. Also, there was a time dependent increase in MDA levels in the kidney homogenate and they were higher in the subchronix exposure.

Advanced Oxidation Protein Products (AOPP) was good marker for chlorinative stress of derivatives phagocytes determination. Increase of AOPP reflected increase in the formation of $\mathrm{H}_{2} \mathrm{O}_{2}$, enhancement myeloperoxidase activity; and increasing reactivity of free radical to biomolecules containing the amino groups, such as protein in the cell structure $[8,17]$.

In vivo condition, AOPP was produced from macrophages activity which would phagocyted cadmium with released $\mathrm{H}_{2} \mathrm{O}_{2}$ and superoxide anion. $\mathrm{H}_{2} \mathrm{O}_{2}$ compound would be catalyzed by myeloperoxidase and formed hypochlorite anion $\left(\mathrm{HOCl}^{-}\right)$. Furthermore, hypochlorite anion reacted with the amino groups of protein to formed chloramine. If the endogenous antioxidant capacity was not able to reduced reactivity of hypochlorite anion, chlorinative stress would be occured [8]. Thus, if the chlorinative stress occured in the kidney, the AOPP levels also increased. 
In addition, the AOPP was also one of biochemical parameter indicated protein oxidative damage, primarily albumin. The damage was caused by free radicals and oxidant compound, and characterized by the structural modifications of proteins that showed with formation of dityrosine cross-link, disulfide bond, and carbonyl groups [18-19]. AOPP could be formed during the glycation process by forming $\mathrm{H}_{2} \mathrm{O}_{2}$ as residue molecule produced through oxidation of 2,3-enediol with presence of $\mathrm{Cd}$ and oxygen. On the other hand, due to the Fenton and Harber-Weiss reaction, $\mathrm{H}_{2} \mathrm{O}_{2}$ was converted into highly reactive hydroxyl radical. This hydroxyl radical would oxidize tyrosine aromatic amino acid residue into dityrosine, tryptophan into hydroxytryptophan, and phenylalanine into 2,3-hydroxyphenylalanine. In addition, hydroxyl radical also oxidized cysteine, methionine, and histidine, so that the protein structure to be modified [20-21].

Increase of AOPP levels caused kidney disorder characterized by tubular fibrosis and glomerulosclerosis, proteinuria which led to kidney dysfunction [22]. Kidney disorder was started from the amino acids oxidation from protein that made up the cell membrane, resulted in deformation of biomolecule structure of cell membrane constituent. This condition affected the osmotic pressure of the kidney and activity of $\mathrm{Na}^{+} \mathrm{K}^{+}$-ATP ase enzyme [23].

The results of this study was consistent with our previous study, which concluded that four weeks of $\mathrm{Cd}$ exposure through the drinking water could increased the AOPP level. Cd exposure would result in respiratory burst involving NADPH oxidase activation to formed superoxide anion and other free radicals. Reaction of free radical with protein caused modifications of protein, measured as AOPP. In addition, formed superoxide anion modulated the production of TNF- $\alpha$, which was one of the proinflammatory factor. Between AOPP and TNF- $\alpha$ showed strong positive correlation, so AOPP could be used as inflammation parameter of the kidney $[17,23]$. Besides as inflammation and oxidative stress parameters, AOPP also played important role as cellular homeostasis. AOPP could provide information about the molecular mechanisms underlying kidney disorder related to oxidative stress. AOPP was modified form of cellular protein that could lead to kidney dysfunction, [23]. The modification included formation of disulfide bond from amino acid containing cysteine, which could be used as cellular redox sensor.

\section{CONCLUSION}

Subacute and subchronic of cadmium exposure significantly triggered lipid peroxidation and chlorinative stress, indicated by increasing levels of MDA and AOPP.

\section{REFERENCES}

[1] Kazantzis, G. 2004. Cadmium, Osteoporosis and Calcium Metabolism. BioMetals. 17. 493-498.

[2] Komari, N., U. Irawati, E. Novita. 2013. Kandungan Kadmium dan Seng pada Ikan Baung (Hemibagrus nemurus) di Perairan Trisakti Banjarmasin Kalimantan Selatan. Sains dan Terapan Kimia. 7 (1). $42-49$.

[3] Pinandari, A.W., D.W. Fitriana, A. Nugraha, Suhartono E. 2011. Uji Efektivitas dan efisiensi Filter Biomassa menggunakan sabut kelapa (Cocos nucifera) sebagai Bioremoval untuk menurunkan Kadar logam (Cd, Fe, Cu), Total Padatan tersuspensi (TSS) dan meningkatkan $\mathrm{pH}$ pada Limbah Air Asam Tambang. Jurnal Prestasi. 1 (1). 1-12.

[4] Sofarini, D., Abdurrahman, R. Ichsan. 2010. Studi analisis pengujian $\mathrm{Cd}$ pada badan air, biota, dan sedimen di Perairan Muara DAS Barito. Jurnal Bumi Lestari. 10(1). 28-37.

[5] Rahman, A. 2006. Kandungan Cd Timbal $(\mathrm{Pb})$ dan Kadmium (Cd) pada beberapa jenis Krustasea di Pantai Batakan dan Takisung Kabupaten Tanah laut Kalimantan Selatan. Bioscientiae. 3(2). 93-101.

[6] Afolabi, O.K., E.B. Oyewo, A.S. Adekunle, O.T. Adedosu, A.L. Adedeji. 2012. Impaired lipid levels and inflammatory response in rat exposed to Cadmium. Exp. Clin. Sci. J. 11. 677-687.

[7] Olszowski, T., I. Baranowska-Bosiacka, I. Gutowska, D. Chlubek. 2012. Pro-Inflammatory Properties of Cadmium. Acta Biochemica Polonica. 59(4). 475-482.

[8] Setiawan, B., N. Kania, A. Yuwono, Paramita D. 2011. Efek inhalasi debu batubara terhadap stres klorinatif dan kerusakan Endotel. J. Indonesian Med. Assoc. 61. 2537.

[9] Del Rasso, N.J., B.D. Foy, J.M. Gearhart, Frazier. 2003. Cadmium uptake in Rat Hepatocytes: correction for Albumin Binding. Toxicol. Sci. 72. 19-30.

[10] Sudarmaji, J. Mukono, I.O. Corie. 2006. Toksikologi Cd B3 dan dampaknya terhadap 
kesehatan. Jurnal Kesehatan Lingkungan. 2(2). 129-142.

[11] Mishra, U.K., S.E. Jacobs, L.W. Doyle, S.M. Garland. 2006. Newer approaches to the Diagnosis of Early Onset Neonatal Sepsis. ADCFN. 91. F208-F212.

[12] Sarsat, V.W., M. Friedlander, T.N. Khoa, C.C. Blandin, A.T. Nguyen, S. Canteloup, J.M. Dayer, P. Jungers, T. Driieke, B.D. Latscha. 1998. Advanced oxidation protein products as novel mediators on inflammation and monocyte activation in chronic renal failure. J. Immunol. 161. 2524-2532.

[13] Ayala, A., M.F. Muñoz, S. Argüelles. 2014. Lipid peroxidation: production, metabolism, and signaling mechanisms of Malondialehyde and 4-Hydroxy-2-Nonenal. Oxid. Med. Cell. Longevity. 1-31.

[14] Kara, H., F. Karatafi, H. Canatan. 2005. Effect of single dose cadmium chloride administration on oxidative stress in male and female rats. Turk. J. Vet. Anim. Sci. 29. 37-42.

[15] Tezcan, O., D. Pandir, H. Bas. 2012. The effects of cadmium on enzymatic antioxidant system and lipid peroxidation of human erythrocytes in vitro and the protective role of plasma level of vitamin C and E. Pol. J. Environ. Stud. 21(6). 18491854.

[16] Aflanie, I., R. Muhyi, E. Suhartono. 2015. Effect of heavy metal on Malondialdehyde and advanced oxidation protein products concentration: a focus on Arsenic, Cadmium, and Mercury. J. M. Bioeng. 4(4). 332-337.

[17] Suhartono, E., Triawanti, A.S. Leksono, M.S. Djati. 2014. Oxidative stress and Kidney Glycation in rats exposed Cadmium, Int. J. Chem. Eng. Appl. 5(6). 497-501.

[18] Suhartono, E., B. Setiawan, Mashuri, M. Juniarti, I. Kamilah, Haudiyah. 2008, Modifikasi protein akibat pembebanan glukosa dengan model reaksi Glikasi Nonenzimatik in vitro. Mutiara Medika. 8(1). 40-47.

[19] Šonka, K., L. Fialová, J. Volná, P. Jiroutek, J. Vávrová, D. Kemlink, M. Pretl, M. Kalousová. 2008. Advanced oxidation protein products in obstructive sleep Apnea. Prague Med. Report. 109(2-3). 159-165.

[20] Mujika, Jl., J. Uranga, JM. Matxain. 2013. Computational study on the attack of $\mathrm{COH}$ radicals on Aromatic Amino Acids. Chem. Eur. J. $19.6862-6873$.
[21] Suto, D., Y. Ikeda, J. Fujii, Y. Ohba. 2006. Structural analysis of Amino Acids, oxidized by reactive oxygen species and an antibody against N-Formylkynurenine.J. Clin.Biochem. Nutr. 38. 1-5.

[22] Sundaram, S.P.M., S. Nagarajan, A.J.M. Devi. 2014. Chronic Kidney disease-effect of oxidative stress. Chinese J. Biol. 1-6.

[23] Uzun, D., G.G. Korkmaz, M.E. Sitar, T. Cebe, K. Yanar, U. Çakatay, S. Aydın. 2013. Oxidative damage parameters in renal tissues of aged and young rats based on gender. Clin. Interv. Aging. 8. 809-815. 